\title{
AGNPS: A Software Program for Assessing Nonpoint Source Pesticide Pollution
}

Dan J. Pantone ${ }^{1}$ and Robert A. Young ${ }^{2}$

Summary. N onpoint-source pesticide pollution from horticultural and other agricultural activities is a primary factor determining the quality of surface water. A menu-driven, interactive pesticide transport submodel has been developed for the agricultural nonpoint-source (AG N PS) pollution model. A G N PS simulates the surface transport of pesticides, sediment, and water from the headwaters to the outlet in a stepwise manner so that an assessment can be made at any point within a watershed boundary. The model can be used by farmers, agricultural extension agents, agrichemical industry workers, or researchers to develop agricultural activities that minimize the surface transport of pesticides. This user-friendly pesticide transport model is available at no cost to users through the Internet.

Additional index words, erosion, Internet, models, runoff, water quality

A

pesticide transport submodel has been developed for the agri-cultural nonpoint-source (AGN PS ) pollution model. The model can predict the surface transport of pesticides in watersheds that have horticultural or other agriculture activities as their primary use. The submodel includes a pesticide database with most of the commonly used herbicides, insecticides, fungicides, and nematicides. The pesticide database may be altered, and new pesticides may be added. In addition to pesticides, AG N PS can simulate the transport of runoff, sediment, and nutrients. $\mathrm{N}$ utrients included in the model are $\mathrm{N}$ and $\mathrm{P}$, both essential plants nutrients. They are two of the most important factors involved in surface water pollution. The model also includes chemical oxygen demand (COD), a common measure of the oxygen required to oxidize organic and inorganic compounds. COD is an important indicator of the degree of water pollution. Pesticide transport, hydrology, erosion, and sedimentation are the basic model components. The model considers point sources of sediment from gullies, streambanks, and construction sites. 
Additional point-source inputs include water, sediment, nutrients, and COD from animal feedlots and springs. Water impoundments, such as reservoirs and tile-outlet terraces, are treated as depositional areas of sediment and sediment-associated nutrients.

Basically, the model divides the watershed into cells and operates on a cell basis. C ellsare square and dividethewatershed into distinct areas. This allows analyses at any point in the watershed. Pesticides and other pollutants are routed from cell to cell in a stepwise manner, thereby allowing the examination of flow at any point between cells. Watershed characteristics and parameters are the inputs for each cell (Fig. 1). C ell sizesmay be adjusted to allow for more detailed analyses of critical areas. For example, if a watershed exceeds 2000 acres, it is recommended that cell sizes of 40 acres be used. For a smaller watershed, smaller cells are recommended. In general, the accuracy of the results can be increased by using smaller cells. $\mathrm{H}$ owever, additional time and expense may be needed to input the parameters required to run the model. I nversely, making the cells larger reduces time and expense, but these savings must be weighed against the possible loss of accuracy due to larger cells.

Basic model inputs include information on pesticide use, precipitation, soils, land use, upland and channel drainage, agricultural management, and point sources of pollution. The USDA-N ational Resource Conservation Service (NRCS) curve number method isused to calculatethe run off volume (U SD A, 1972). T wo methods are used to calculate thepeak flow rate. 0 neisan empirical method developed by Smith and Williams (1980) and used in the CREAM S model (Knisel, 1980). Alternatively, a simple method developed by the USDA to estimate runoff and peak discharges in small watersheds can be used (U SD A, 1986). Regardless of the method used, triangular hydrographs are generated for each cell based on the peak flow rates.

\section{Model description}

Soil erosion and routing. The universal soil loss equation (USLE) is used to calculate upland erosion (Wischmeier and Smith, 1978). Soil erosion is estimated for each cell, and the sediment is partitioned into five particle size classes (clay, silt, small aggregates, large aggregates, and sand). Additionally, the type of channel erosion can be input into the model. The model calculates runoff and upland erosion for each cell, and sediment is routed from cell to cell using the sediment transport methods described by Foster et al. (1981) and Lane (1982). The amount of sediment (sediment load) leaving a cell is calculated for each particle size class. The model allows the user to determine whether or not deposition and scouring occurs during channel flow. This feature is important in the case of a nonerodible channel bed.

The model simulates the transport of pesticides, $N, P$, and COD through the watershed. M ost of the basic relationships used to estimate chemical transport have been adapted from either the CREAM S model (Frere et al., 1980) or the feedlot model of

\begin{tabular}{|c|c|c|c|c|c|c|c|}
\hline$<F 1>-$ Help $<F 2>-$ Ment & $\angle F 3>-L$ & $\operatorname{ad}<\mathrm{F} 4$ & -Save & $<F 5>-Q$ & Lit $\angle F B>$ & Initial D & ate \\
\hline Cell Number.......... & 1 & 2 & 3 & 4 & 5 & 6 & 7 \\
\hline Cell Division......... & 000 & 000 & 000 & 000 & 000 & 000 & 100 \\
\hline Rec. Cell Number.. & 4 & 1 & 7 & 7 & 4 & 5 & 7 \\
\hline Rec. Cell Div .......... & 000 & 000 & 220 & 220 & 000 & 000 & 230 \\
\hline Flow Direction........ & 5 & 7 & 5 & 6 & 7 & 7 & 3 \\
\hline SCS Curve Number & 74 & 74 & 74 & 74 & 78 & 82 & 100 \\
\hline Land Slope $(\%), \ldots \ldots$. & 0.9 & 0.8 & 0.8 & 1.1 & 1.1 & 0.8 & 0.0 \\
\hline Slope Shape ......... & 1 & 1 & 1 & 1 & 3 & 7 & 1 \\
\hline Slope Length ( $f$ )..... & 100 & 100 & 100 & 100 & 100 & 100 & 0 \\
\hline Overtand Manning's... & 0.103 & 0.130 & 0.103 & 0.027 & 0.071 & 0.130 & 0.990 \\
\hline $\mathrm{K}$ - Factor........... & 0.28 & 0.28 & 0.32 & 0,32 & 0.30 & 0.29 & 0.00 \\
\hline C - Factor............ & 0.5000 & 0.4300 & 0.5100 & 0.5000 & 0.6000 & 0.4300 & 0.0000 \\
\hline $\mathbf{P}$ - Factor........... & 1.00 & 1.00 & 1.00 & 1.00 & 1.00 & 1.00 & 0.00 \\
\hline Surf Cond Constant... & 0.29 & 0.29 & 0.21 & 0.23 & 0.12 & 0.29 & 0.00 \\
\hline COD Factor........... & 86 & 80 & 110 & 88 & 125 & 80 & 0 \\
\hline Soll Texture & 2 & 2 & 2 & 2 & 2 & 3 & 0 \\
\hline Fertilizer Indicator. & $\hbar$ & 1 & 1 & 1 & 1 & 1 & 0 \\
\hline Pesticide Indicator... & $i$ & 0 & 0 & 0 & 0 & 0 & 0 \\
\hline Point Source Ind..... & 0 & 0 & 0 & 0 & 0 & 0 & 0 \\
\hline Additional Erosion.... & 0 & 0 & 0 & 0 & 0 & 0 & 0 \\
\hline Impoundment Ind....... & 0 & 0 & 0 & 0 & 0 & 0 & 0 \\
\hline Chanmel Indicator.... & 1 & 1 & 1 & 1 & 1 & 1 & 0 \\
\hline $\begin{array}{l}<F 7>-G o \text { To } \angle F B>-C o p \\
<\text { AltF }>- \text { Delete Cell }<\end{array}$ & $\begin{array}{l}\text { Cell }<F \\
\mathrm{ItF}>-\mathrm{Dr}\end{array}$ & $\begin{array}{l}\text { P-Copy } \\
\text { ide Cell }\end{array}$ & $\begin{array}{l}\text { Row }< \\
\text { CAltE-4 }\end{array}$ & $10>-S e$ & $\begin{array}{l}\text { arch Row } \\
<\text { Alt }=5\rangle\end{array}$ & $\begin{array}{l}<A \mid t F 1 \\
-P_{\text {rint }}\end{array}$ & 1)-Clear \\
\hline
\end{tabular}

Fig. 1. Main spreadsheet. Pesticide applications can be indicated by putting a value of 1 in the Pesticide Indicator field. 


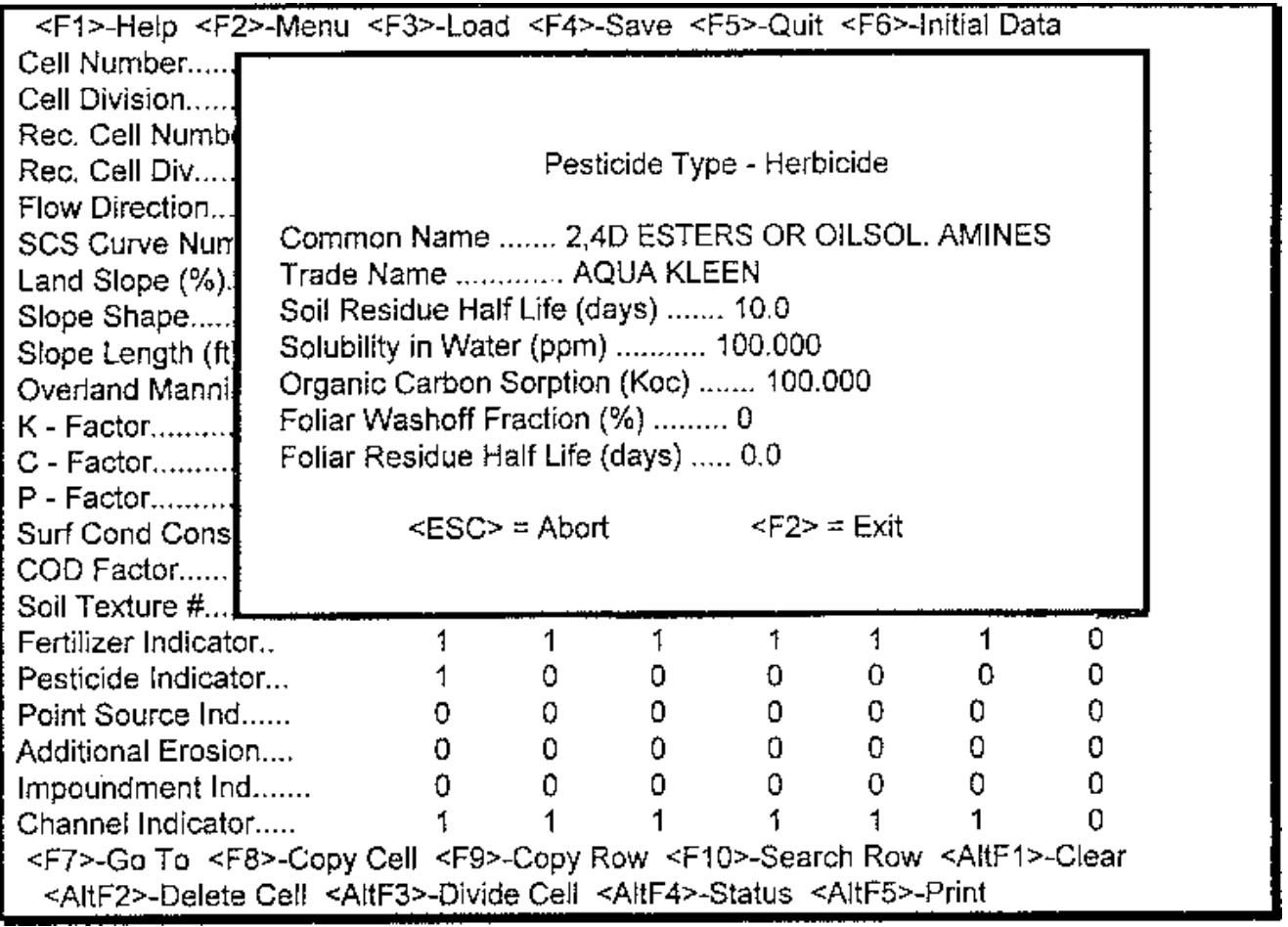

AGNPS is not limited to nonpoint sources of pollution. For example, point sourcesof nutrientsand COD from animal feedlots can be included in themodel. A feedlot pollution model developed by Young et al. (1982) is used as a subroutine to estimate chemical contributions from feedlots. Point sources of water and nutrients, such as springs and wastewater treatment plant discharges, can be accounted for on a cell by cell basis. In addition, sediment from eroding streambanks and streambeds can be treated as point sources. These point sources of sediment are ad ded to the upland sediment. Similarly, point sources of nutrients are added to the other nutrient inputs to a cell and routed from cell to cell. Rout-

Fig. 2. Pesticide database utility. A pop-up window allows users to accept or edit the parameters provided by the pesticide database.
Young et al. (1982). D ifferent chemical transport calculations are used depending on whether the chemical is soluble or attached to the sediment. The amounts of nutrients in the rainfall and fertilizers are used to estimate the soluble nutrients. The model assumes that the COD is soluble. Generally, pesticides, soluble nutrients and COD are not stable, and, depending on the length of time they are present, calculations are used to estimate the amount of chemical decay. ing of sediment and runoff through impoundments is estimated using the equations developed by L aflen et al. (1978).

Pesticide transport. Pesticides can be chosen from a pesticide database that suggests parameter values for a given pesticide (Fig. 2). Parameters, such as the soil

Fig. 3. Preplant pesticide application. A pop-up window allows users to provide parameters associated with applying pesticides preplant.

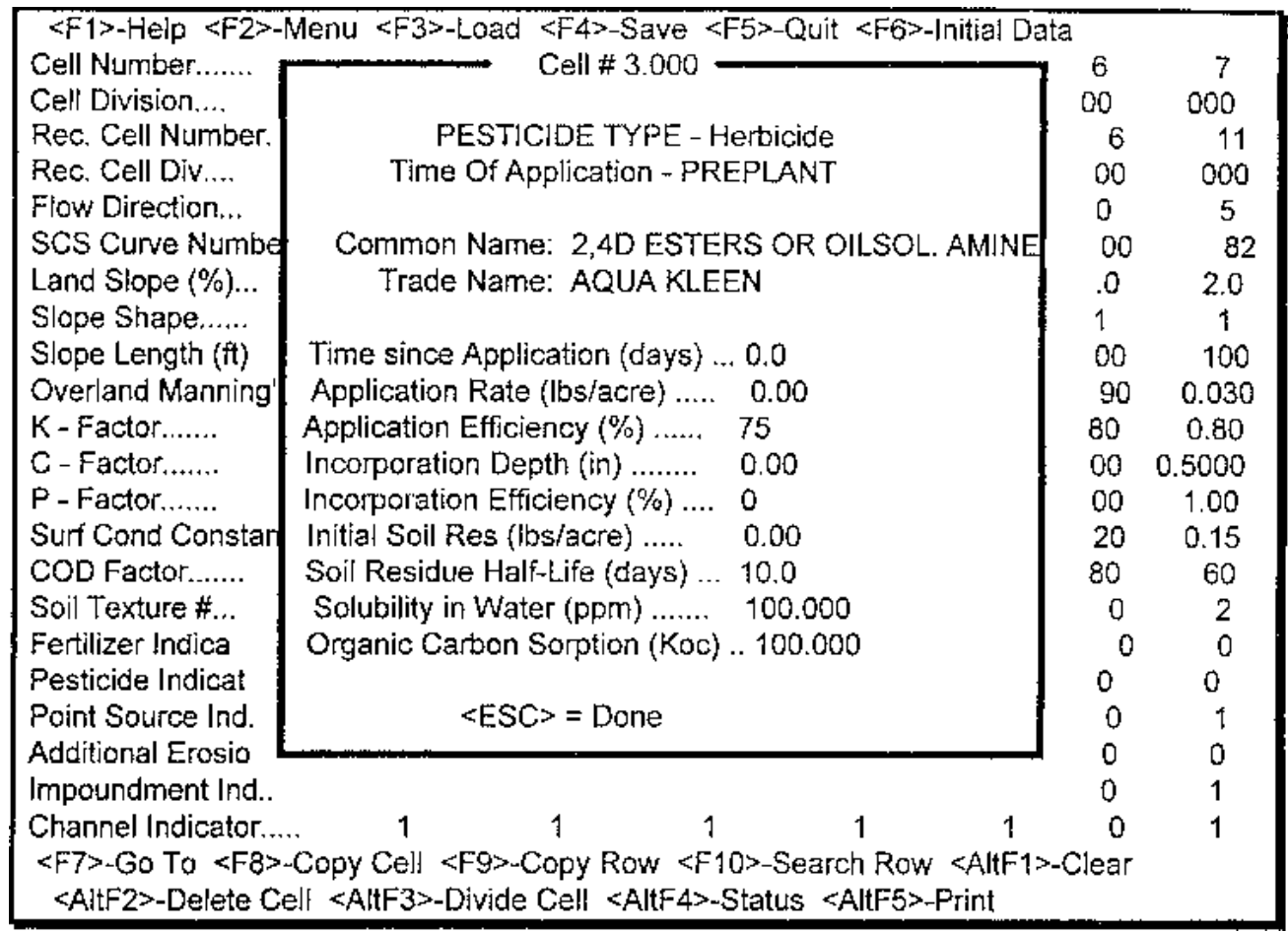


Fig. 4. Preemergence pesticide application. A pop-up window allows users to provide parameters associated with applying pesticides preemergence.

residue half-life or the solubility in water, can bechanged and saved. Pesticides can be applied either preplant (Fig. 3), preemergence(Fig. 4), or postemergence (Fig. 5).

The pesticide transport submodel incorporates technology from the research of Leonard et al. (1987) involving the groundwater loading effects of agricultural management systems (GLEAM S) model and from Arnold et al. (1990) involving the simulator for water reso urces in rural basins (SWRRB) model. The basic technology incorporated in GLEAMS and SWRRB has been validated (Arnold and Williams, 1987; Knisel, 1980; L eonard et al., 1987; L eonard and Wauchope, 1980). In addition, AGN PS pesticide transport includes many important modifications. Some of the most important modifications are the cellular nature of AGN PS, which is different from GLEAM S and SWRRB, and the method by which pesticides are routed (Young et al., 1989).

N ot all of the pesticide applied reaches

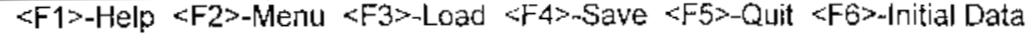
Celt Number....... Cell Division....

Rec. Cell Number.

Rec. Cell Div....

Flow Direction...

Scs Curve Number. Land Slope (\%)...

Slope Shape.....

Slope Length ( $t$ )

Overland Manning'

$K$ - Factor.......

C - Factor......

$P$ - Factor......

COD Factor......

Soil Texture \#..

Fertilizer indica

Pesticide Indicat

Point Source Ind

Additional Erosion....

Impoundment tind.......

Channel Indicator

$<F 7>-G 0$ To $<F B>$-Copy Cell $<F G>$-Copy Row $<$ F $10>-$ Search Row $<$ AltF $1>-C l e a r$

PESTICIDE TYPE - Herbicide

Time Of Application - PREEMERGENCE

Common Name: $2,4 \mathrm{D}$ ESTERS OR OLLSOL. AMINE Trade Name: AQUA KLEEN

Time since Application (days) ... 0.0

Application Rate (lbs/acre) ..... 0.00

Application Efficiency $(\%), \ldots . .75$

Initial Soil Res (lbs/acre) ..... 0.00

Soil Residue Half-Life (days) ... 10.0

Solubility in Water (ppm) ....... 100.000

Organic Carbon Sorption (Koc) ... 100.000

$$
\angle E S C=\text { Done }
$$

1

\begin{tabular}{|c|c|c|c|}
\hline \multicolumn{2}{|c|}{ 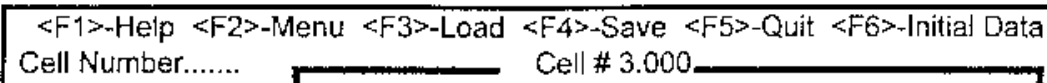 } & 6 & 7 \\
\hline Cell Division.... & & 00 & 000 \\
\hline Rec. Cell Number. & PESTICIDE TYPE - Herbicide & 6 & 11 \\
\hline Rec Cell Div.... & Time Of Application - POSTEMERGENCE & 00 & 000 \\
\hline Flow Direction... & & 0 & 5 \\
\hline SCS Curve Number. & Common Name: 2,40 ESTERS OR OILSOL. AMINES & 00 & 82 \\
\hline Land Slope $(\%) \ldots$ & Trade Name: AQUA KLEEN & .0 & 2.0 \\
\hline Slope Shape..... & & 1 & 1 \\
\hline Slope Length (ft) & Time since Application (days) ... & 00 & 100 \\
\hline Overland Manning' & Application Rate (lbs/acre) ..... & 90 & 0.030 \\
\hline K - Factor....... & Application Efficiency $(\%)$...... & 80 & 0.80 \\
\hline $\mathrm{C}$ - Factor....... & Percent Canopy Cover ............. & 00 & 0.5000 \\
\hline P - Factor...... & Initial Foliar Res (lbs/acre) ... & 00 & 1.00 \\
\hline Surf Cond Constan & Initial Soil Res (lbs/acre) & 20 & 0.15 \\
\hline COD Factor....... & Foliar Washoff Threshold (in) ... & 80 & 60 \\
\hline Soit Texture \#... & Foliar Washoff Fraction (\%) ..... & 0 & 2 \\
\hline Fertilizer Indica & Foliar Res Half-Life (days) ..... & 0 & 0 \\
\hline Pesticide Indicat & Soil Residue Half Life (days) ... $\quad 10.0$ & 0 & 0 \\
\hline Point Source Ind. & Solubility in Water (ppm) ...... 100.000 & 0 & 1 \\
\hline Additional Erosio & Organic Carbon Sorption (Koc) ... 100.000 & 0 & 0 \\
\hline impoundment ind.. & & 0 & 1 \\
\hline Channel Indicator & $\angle E S C>=$ Done & 0 & 1 \\
\hline
\end{tabular}
$\angle A l t F 2>-$ Delete Cell $<$ AltF $3>$-Divide Cell $<$ AltF $4>-$ Status $<A$ ittF $5>$-Print

the soil surface. D epending on the application efficiency, only a portion of the applied pesticide is available for pesticide transport (Fig. 6). In addition, a certain percentage is intercepted by the plant canopy. The amount of pesticide intercepted by the foliage is cal-

Fig. 5. Postemergence pesticide application. A pop-up window allows users to provide parameters associated with applying pesticides postemergence. 
culated from the fraction of the ground that is covered with the plant canopy. Therefore, the amount of pesticide that penetrates the plant canopy and isinitially on the soil surface is determined by the plant canopy cover. Pesticide decay is influenced by temperature, soil water content, organic matter, and $\mathrm{pH}$. For most pesticides, insufficient data areavailable to construct a model of the individual effects of these factors. Therefore, a more generalized equation that lumps the individual processes involved in pesticide decay is used. The degradation of pesticides on the foliar surface is not necessarily the same as that in the soil and is estimated as a first-order process with its own half-life.

During a rainfall, pesticides may be washed from the foliage to the soil surface depending on the rainfall amount and the specific pesticide involved (Fig. 6). Several methods have been developed to account for pesticide washoff. Various generalized equations that incorporate empirically derived relationships have been developed for various groups of pesticides (Willis and M CD owell, 1987). The total amount of pesticide in the soil surface iscalculated by adding thewashoff from the foliar surface.

The amount of water that leaches from the soil surface, carrying dissolved pesticide with it, is based on the effective infiltration, rainfall, runoff, and surface storage (Fig. 6). The surface storage describes the saturation of the top $1 \mathrm{~cm}$ of soil. The top $1 \mathrm{~cm}$ is the surface interaction layer where pesticide is available for surface transport. To estimate the amount of pesticide leached from the surface interaction zone, the model uses an equation that includes the pesticide available for surface transport, the soil specific gravity, the soil-water partitioning coefficient, and the soil porosity. The pesticide load (mass) of the soil surface interface layer is converted to concentration, based on the bulk density of the soil. An extraction ratio approach is used to estimate the concentration of pesticide in the runoff water and the sediment (L eonard and Wauchope, 1980). The pesticide concentration in the runoff water is based on the pesticide concentration in the runoff water and the extraction coefficient. A similar algorithm is used to calculate the pesticide concentration in the suspended sediment. To estimate the concentration of the pesticide, an enrichment ratio approach is used. The enrichment ratio is defined as the pesticide concentration in the sediment compared to the concentration in the soil. The enrichment ratio is used to calculate the pesticidequantity and concentration in the runoff water or attached sediment at the outlet of each cell. During transport, pesticides may be transported to any given receiving cell from cells above it in the watershed. Therefore, we know the quantity of pesticide entering the cell and theamount of pesticideal ready present and available for transport. $\mathrm{H}$ owever, in the receiving cell, the total quantity of pesticide is redistributed into the runoff water and sediment.

The submodel used for pesticide transport (i.e., the technology) has been validated (J ames Wolf, U.S. Environmental Protection Agency, personal communication). H owever, incorporating this technology into a watershed-based model and validating it is much more involved. The expenses involved in developing watershed-size plots, applying various pesticides, and monitoring pesticide transport over a period of yearscan amount to several million dollars. The irony is that in an era of tight monetary policy, models are being developed as an alternative to actual field experiments. This is why it has been so difficult to validate the full model.

\section{Model outputs}

The model allows the user many output options. Basic outputs for the watershed include estimates of the volume of runoff and the peak flow rate at the watershed outlet. The amount of area-weighted erosion for upland and channel erosion also is estimated. Additional outputs are given for the sediment, including the delivery ratio, enrichment ratio, mean sediment concentration, and total yield for each of five particle size classes. In addition, a nutrient analysis is available. Nutrient concentrations and mass per unit area are estimated for $\mathrm{N}, \mathrm{P}$, and CO D in the sediment and the runoff.

In addition, outputsfor pesticide concentrations and mass loads may be obtained. If desired, these outputs can begenerated for any specified cell. The specific cell or cells a user may want to select depends on the problem involved. For example, if a specific pesticide is of interest, only those cells where that pesticide is applied (or the cells below) would be of interest. If the model reveals a problem with a pesticide in a specific cell, upland cells may be examined to identify the problem areas. Once identified, alternative management strategies can be used, thereby minimizing the potential pesticide pollution problem.

If the output reveals that a specific cell is too large to depict conditions sufficiently, or if a problem area exists that should be looked at in more detail, the cell division capability of themodel permitsany given cell to bedivided into fourths. Cell division can be repeated three times, the result being cells one-sixtyfourth the size of the original cell. Therefore, more precise analyses of critical areas may be made at desired points in the watershed.

Included with the model are several ex- 
ample watersheds complete with input parameterscharacterizing thewatersheds. These watershedscan be used to generate resultsfor pesticide transport and show how they can be applied for management decisions. For example using the A G W7 watershed and applying atrazine postemergent at a rate of $3 \mathrm{lb} /$ acre to Cell 1, atrazine is found to be transported much further down the watershed drainage to C ell 11, even though no pesticide was applied there. $\mathrm{H}$ owever, if a lower rate (1 $\mathrm{lb} /$ acre) is applied, no appreciable atrazine transport is predicted for Cell 11 . I f C ell 11 is a critical area where pesticides are to be avoided, lower application rates might be preferable. In the above example, the period between pesticideapplication and rainfall was set at 3 days and postemergence applications were used.

\section{Future modifications}

Currently, AGNPS is a single-event model. That is, this model simulates a single rainfall at a time rather than on a continuous daily basis as do some models. H owever, currently the model is being annualized to overcome this limitation. That is, the model will continuously simulate rainfall events and provide average annual responses of the watershed. By annualizing the model, it will be possible to provide a more detailed description of the hydrological events that result in the transportation of pesticidesfrom the field into the adjacent environment.

Most of the basic technology of the single-event model will be incorporated into the annualized version. However, several important changes will be included in the new model. $O$ ne important change is the use of a weather generator ( $\mathrm{N}$ icks and Lane, 1989) to simulate rainfall for specific geographical areas. C urrently, AGN PS is limited to using user inputs. By using a weather generator, it will be possible to predict the average response expected for a specific period of time during which the model operates on a daily time step. For example, if a farmer wants to know if a fall application of a certain pesticide generally will result in less pesticide runoff than a winter application, he can optimize his pesticide applications by using the model. O ne other important change in the annualized version of AGN PS is that erosion will be calculated by using a revised universal soil loss equation (RU SLE). Another limitation of the single-event model is that pesticide transport vertically through the soil is not described. The annualized model will allow the user to divide the soil profile into layersand will include detailed assessments of pesticidetransport through theselayers. These changes will increase the flexibility and accuracy of the model.

\section{Conclusions}

AGNPS is a user-friendly model that can be used to estimate the quantity and concentration of pesticides in the runoff and sediment from agricultural watersheds. The model is a distributed parameter simulation model used to assess the effects of alternate agricultural management systems on nonpointsource pollution and identify critical areas of pollution production and accumulation within the watershed. This model is one of the few models that operates on a cell basis, meaning the watershed is divided into uniform grids for input and analysis; all parameter inputs and calculationsaremadeat the cell level. The model can be used by growers, agricultural extension agents, agri-chemical industry workers, and scientists to develop agricultural activities that minimize the transport of pesticides from the field where they are applied. The model provides outputs that indicate how much pesticiderun off is being generated and transported. Additionally, the outputs indicate the source of the pesticides, including any areas delivering high levels of pesticides to surface waterways. Perhaps the most important feature of the model is the capability to simulate various alternative agricultural management options (e.g., cropping systems, tillage treatments, and pesticide application methods) on thetransport of pesticides in the environment. Pesticide runoff due to horticultural and agricultural activities undoubtedly will be important for many years to come. By optimizing agricultural activities, potential pesticide pollution can be minimized.

\section{Internet availability}

Version 5.0 of AGNPS may be downloaded from an anonymousftp site by executing thefollowing commandsat theftp prompt: "open soils.mrsars.usda.gov" <return>, anonymous" $\triangleleft$ return $>$, "yourE-mail address" বreturn>, "cd pub/ agnps500" বreturn>, "bin" <return>, and "get about.txt" <return>. O nce you have downloaded the file, read it for further information. Through the Internet, not only can you download the model, but you can obtain a copy of the user's manual. Additionally, comments or ques- 
tions can be sent easily via the Internet to agnps_support@mail.mrsars.usda.gov.

In the future, the Internet will allow users to obtain easily the various parameters needed to run the model. For example, various soil and pesticide parameters needed by the model will be obtainable through the Internet.

\section{Literature Cited}

Arnold, J.G. and J.R. Williams 1987. Validation of SWRRB-simulator for water resources in rural basins. J. Water Resources Planning M gt. 113:243-256.

Arnold, J.G., J.R. Williams, A.D. N icks, and N .B. Sammons. 1990. SWRRB: A basin scale simulation model for soil and water resources management. Texas A\& M Press.

Foster, G.R ., L.J. Lane, J.D. N owlin, J.M . Laflen, and R.A. Y oung. 1981. Estimating erosion and sediment yield on field-sized areas. Trans. ASAE 24:1253-1262.

Frere, M.H ., J.D. R oss, and L.J. Lane. 1980. The nutrient submodel, p. 65-85. In: W.G. Knisel (ed.) CREAM S, a field scale model for chemicals, runoff, and erosion from agricultural management systems. U SD A Conserv. Res. R pt. 26.

K nisd, W.G. (ed.). 1980. CREAM S, a field scale model for chemicals, runoff, and erosion from agricultural management systems. U SD A C onserv. Res. Rpt. 26.

Laflen, J.M., H .P. Johnson, and R.O. H artwig. 1978. Erosion modeling on impoundment terraces. Trans. ASAE 21:1131-1135.

Lane, L.J. 1982. D evelopment of a procedure to estimate runoff and sediment transport in ephemeral streams, p. 275-282. In: Recent developments in theexplanation and prediction of erosion and sediment yield. Proc. Exeter Symp. IAHS Publ. 137.
Leonard, R.A ., W.G. K nisel, and D .A. Still. 1987. GLEAM S: Groundwater loading effects of agricultural management systems. Trans. ASAE 30:1403-1418.

Leonard, R.A. and R.D. Wauchope 1980. The pesticide submodel, p. 88-112. In: W.G. Knisel (ed.). CREAM S, a field scale model for chemicals, runoff, and erosion from agricultural management systems. U SD A Conserv. Res. Rpt. 26.

$\mathrm{N}$ icks, A .D . and L.J . Lane 1989. Weather generator. In: U SD A water erosion prediction project: $\mathrm{H}$ illslope profile model documentation. NSERL Rpt. 2.

Smith, R.E. and J.R. Williams. 1980. Simulation of surface water hydrology, p. 13-35. In: W.G. Knisel (ed.). CREAMS, a field scale model for chemicals, runoff, and erosion from agricultural management systems. U SD A Conserv. Res. R pt. 26.

U .S. D epartment of A griculture 1972. Hydrology. Soil Conservation Serv. Natl. Eng. H dbk. Washington, D.C. Section 4, p. 10.5-10.6.

U .S. D epartment of A griculture. 1986. U rban hydrology for small watersheds. Soil Conservation Serv, Eng Div, Tech Rpt. 55. Washington, D.C.

Wischmeier, W.H . and D.D. Smith. 1978. Predicting rainfall erosion losses. U SDA H dbk 537. Washington, D.C.

Willis, G.H . and L.L. M CD owell. 1987. Pesticide persistence on foliage. Rev. Environ. Contam. Toxicol. 100:23-67.

Young, R .A., C.A. Onstad, D.D. Bosch, and W.P. A nderson. 1989. AGN PS: A nonpoint-source pollution model for evaluating agricultural watersheds. J Soil Water Conservation 44:168-173.

Y oung, R .A ., M .A . Otterby, and A . R oos. 1982. An evaluation system to rate feedlot pollution potential. ARM -N C-17.

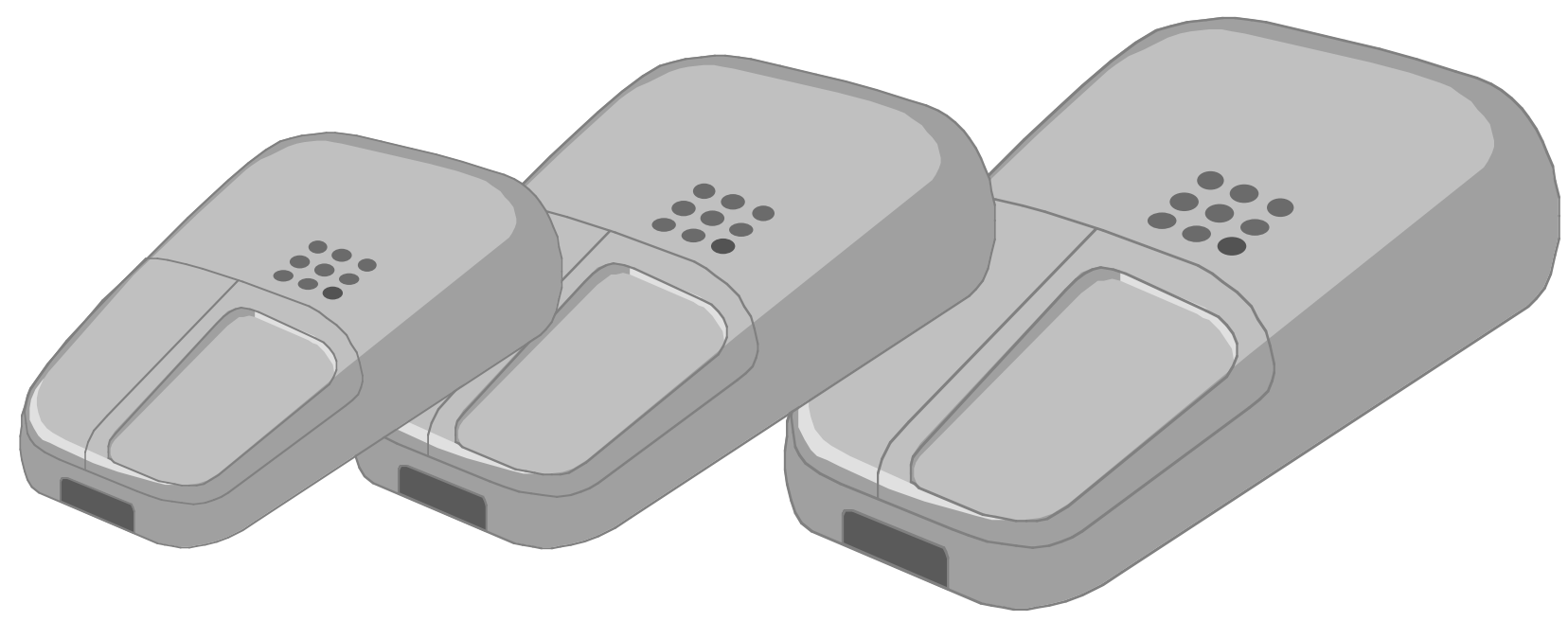

